\title{
Physico-Mechanical Properties of Finished Denim Garment by Stone-Bleach Treatment
}

\author{
Md. Mashiur Rahman Khan ${ }^{1,2}$ and Md. Ibrahim H. Mondal ${ }^{1 *}$ \\ ${ }^{1}$ Polymer and Textile Research Lab., Department of Applied Chemistry and Chemical Engineering, Rajshahi \\ University, Rajshahi 6205, Bangladesh, Mobile: +88-01914-254992; E-mail: mihmondal@yahoo.com \\ ${ }^{2}$ Department of Apparel Manufacturing Engineering, Bangladesh University of Textiles, Tejgaon, Dhaka-1208,
} Bangladesh

\begin{abstract}
Chemical washing of fresh-assembled denim garment is a fundamental finishing process in textile and readymade garment industries and has the largest effect on the physico-mechanical properties on finished denim garment. In this study, modification of denim trousers by washing using pumice stone mixed with bleaching powder was investigated. The fresh-assembled denim trousers, twill 3/1 weave and composition $100 \%$ cotton, have been processed by stone-bleach treatment using parameters namely concentration of bleaching powder (5.0 to $15.0 \mathrm{~g} / \mathrm{L})$ (owl) with $30 \%$ pumice stone (owg) at washing temperature $40^{\circ} \mathrm{C}$ and at $\mathrm{pH} 10.5$ for treatment time 20 min in the fiber to liquor ratio of 1:10 in an industrial sample washing machine. In order to evaluate the influence of these washing parameters on the properties of denim trouser like tensile strength, fabric weight, color change, stiffness and water absorption, has been determined. Fabric surface was also examined by scanning electron microscope (SEM) and fluorescence microscope (FM). It can be concluded that the washing parameters had influenced on the physico-mechanical properties of finished denim garment. Especially stone-bleach treatment helped to get the specific color fading effect and softness of denim garment, which gave a new-look appearance and good wear performance to the fabric distinctly. The results indicate that for producing durable and sustainable denim garment the optimized washing condition for the best value is 10.0 $\mathrm{g} / \mathrm{L}$ bleaching powder mixed with $30 \%$ pumice stone in the stone-bleach treatment.
\end{abstract}

\section{INTRODUCTION}

Denim garment (Jeans) is produced from very strong and stiff fabric. Denim is basically cotton and twillweave fabric that uses colored warps and white/grey weft yarn $[1,2]$. Without washing the fresh assembled denim garment is uncomfortable to wear due to its weaving and dyeing effect, hence it can be finished / modified by washing and introduces new look design and fashion ${ }^{3}$. There have been many attempts to use chemicals in denim garment washing. The most commonly used denim washing methods are enzyme wash, bleach wash, acid wash, stone wash, etc. Although enzymatic method is eco-friendly but enzyme treatment on cellulosic garment degrades cellulose at the ends or in the middle of the cellulose chains, yielding shorter chain cellulose polymers, and reduces its mechanical strength severely $[4,5]$. To minimize the unwanted strength losses and to provide distressed worn out fashion look to the denim garment, stone-bleach washing is carried out with the aid of fixed amount of pumice stone mixed with various concentrations of bleaching powder to achieve the specific washing effects by the customers. Stonebleach wash of denim garment is very popular of today's youth but sufficient literatures of denim garment washing with stone-bleach wash has not been available yet. However, many researchers have been investigated in the past on enzyme washing and bleach washing for denim garment [6-11].

At first denim garments were desized in liquor containing detergent $(1.0 \mathrm{~g} / \mathrm{L})$ and desizing agent (1.5
The major objective of this study is to examine the effect of various concentrations of bleaching powder with a fixed amount of pumice stone, temperature and time in stone-bleach washing to produce today's most preferred fashionable and durable denim garment.

\section{MATERIALS \& METHODS}

\subsection{Materials}

$100 \%$ cotton twill weave (3/1 LHT \& $\left.381 \mathrm{~g} / \mathrm{m}^{2}\right)$, construction $70 \times 42 / 10 \times 9$, indigo dyed denim fabric was used in this investigation. Denim garments (trousers) were manufactured using the stated denim fabric. Detergent (Hostapur, BASF, Germany), desizing agent (Luzyme, BASF, Germany), antistaining agent (India), acetic acid (China), softener (Text-soft, BASF, Germany) and fresh pumice stones(Turkey) of size $(2-3 \mathrm{~cm})$ were used for the experiment. A bleaching powder (Bleach KCI, India) (35\% available chlorine) was used for washing denim garments. In addition, soda ash $\left(\mathrm{Na}_{2} \mathrm{CO}_{3}\right.$, China) was used as buffer to control $\mathrm{pH} 10.5$ in the washing bath $[1,2]$.

\subsection{Methods}

\subsubsection{Pumice Stone-Bleaching Powder Treatment}

$\mathrm{g} / \mathrm{L})$ in a laboratory scale sample washing machine at $60^{\circ} \mathrm{C}$ for $20 \mathrm{~min}$ in material to liquor ratio of $1: 30$. 
After desizing, the garments were treated using bleaching powder mixed with pumice stone in the same sample washing machine at different concentrations of bleaching powder $(5.0-15.0 \mathrm{~g} / \mathrm{L})$ with fixed amount of pumice stone (30\%, owg), fixed at $40{ }^{\circ} \mathrm{C}$ for $20 \mathrm{~min}$. All treatments were involved in the rotary cylindrical sample washing machine at 30 rpm. The washed denim garments were squeezed in a laboratory scale hydro-extractor machine (Zanussi, Roaches, England) at $200 \mathrm{rpm}$ for $4 \mathrm{~min}$ to remove excess water and then dried in a steam drier (Opti-Dry, Roaches, England) at $75^{\circ} \mathrm{C}$ for $40 \mathrm{~min}$. Denim garments were then evaluated in testing machines and characterized of their physical and mechanical properties.

\subsubsection{Testing and Analysis}

Stone-bleach washed denim garments were conditioned at $65 \% \mathrm{RH}$ and at $20^{\circ} \mathrm{C}$ for $24 \mathrm{~h}$ before testing according to ASTM D 1776. Tensile strength and elongation at break was determined by the US Standard Grab test method according to ASTM D5034. Weight loss (\%) in fabric was calculated from the difference in fabric weight (GSM) before and after the treatment according to ASTM D 3776. Stiffness was measured from the bending stiffness in fabric by Shirley stiffness tester according to BS 3356. Changes in the original colour shade of the fabric was rated using Gray scale for colour change according to AATCC evaluation procedure 1. Scanning electron microscopy was studied using SEM (Hitachi, model-S 3400 N, Japan) and Fluorescence microscopy was studied using FM (Olympus, model IX71, Japan).

\section{RESULTS \& DISCUSSION}

Stone-bleach treated denim garments were subjected to treatment with $5.0-15.0 \mathrm{~g} / \mathrm{L}$ bleaching powder mixed with $30 \%$ pumice stone and some physical-mechanical tests were performed to evaluate changes in denim garment. The surface appearances of the untreated/modified denim garments were also studied.

\subsection{Effect of Bleach Concentrations with Pumice Stone}

The effects of $30 \%$ pumice stone (owg) with various concentrations of bleaching powder from 5.0 to $15.0 \mathrm{~g} / \mathrm{L}$ on the properties of denim garments were investigated and are shown in Tables $1-4$.

It can be seen from Table 1 that treatment of denim trousers with $5.0 \mathrm{~g} / \mathrm{L}$ bleaching powder combined with $30 \%$ pumice stone cause a decrease of tensile strength and this decrease was higher at higher bleach concentrations. It is observed that $15.0 \mathrm{~g} / \mathrm{L}$ bleach concentration with $30 \%$ pumice stone exhibited the highest decrease in the loss of tensile strength as compared with the other concentrations. Pumice stone with $5.0 \mathrm{~g} / \mathrm{L}$ bleaching powder caused $15.85 \%$ strength loss in warp direction when the garments were treated without soda ash, and $5.69 \%$ strength loss was observed for the case of with soda ash in washing, and with higher bleach concentrations of $15.0 \mathrm{~g} / \mathrm{L}$, the strength losses are higher, and these are $28.46 \%$ and $19.51 \%$ respectively; whereas, in weft direction the strength losses are $13.97 \%$ and $10.29 \%$ respectively.

Table 1: Effect of tensile strength in warp and weft directions at different concentrations of bleaching powder combined with $30 \%$ pumice stone for denim garment.

\begin{tabular}{c|c|c|c|c}
\hline \multirow{2}{*}{$\begin{array}{c}\text { Bleaching } \\
\text { powder, } \\
(\mathbf{g} / \mathbf{L})\end{array}$} & \multicolumn{2}{|c|}{$\begin{array}{c}\text { Loss in tensile strength in warp } \\
\text { direction, }(\%)\end{array}$} & \multicolumn{2}{c}{$\begin{array}{c}\text { Loss in tensile strength in weft direction, } \\
(\%)\end{array}$} \\
\cline { 2 - 5 } & $\begin{array}{c}\text { Bleaching with } \\
\text { soda ash }\end{array}$ & $\begin{array}{c}\text { Bleaching without } \\
\text { soda ash }\end{array}$ & $\begin{array}{c}\text { Bleaching with } \\
\text { soda ash }\end{array}$ & $\begin{array}{c}\text { Bleaching without } \\
\text { soda ash }\end{array}$ \\
\hline 0.0 & 0 & 0 & 0 & 0 \\
5.0 & 5.69 & 15.85 & 3.68 & 5.88 \\
7.5 & 9.76 & 18.29 & 5.14 & 9.56 \\
10.0 & 15.04 & 21.14 & 8.09 & 11.76 \\
12.5 & 18.70 & 23.58 & 9.56 & 12.50 \\
15.0 & 19.51 & 28.46 & 10.29 & 13.97 \\
\hline
\end{tabular}


Table 2: Effect of elongation at break in warp and weft directions at different concentrations of bleaching powder combined with $30 \%$ pumice stone for denim garment.

\begin{tabular}{c|c|c|c|c}
\hline \multirow{2}{*}{$\begin{array}{c}\text { Bleaching } \\
\text { powder, } \\
(\mathbf{g} / \mathbf{L})\end{array}$} & \multicolumn{2}{|c|}{$\begin{array}{c}\text { Elongation at break in warp direction, } \\
(\boldsymbol{\%})\end{array}$} & \multicolumn{2}{c}{$\begin{array}{c}\text { Elongation at break in weft direction, } \\
(\%)\end{array}$} \\
\cline { 2 - 5 } & $\begin{array}{c}\text { Bleaching with } \\
\text { soda ash }\end{array}$ & $\begin{array}{c}\text { Bleaching without } \\
\text { soda ash }\end{array}$ & $\begin{array}{c}\text { Bleaching with } \\
\text { soda ash }\end{array}$ & $\begin{array}{c}\text { Bleaching without } \\
\text { soda ash }\end{array}$ \\
\hline 0.0 & 0 & 0 & 0 & 0 \\
5.0 & 23.14 & 12.95 & 4.88 & 3.45 \\
7.5 & 20.39 & 12.12 & 3.74 & 2.59 \\
10.0 & 17.08 & 9.64 & 3.61 & 2.01 \\
12.5 & 15.98 & 7.71 & 2.01 & 1.44 \\
15.0 & 14.33 & 6.89 & 2.01 & 1.15 \\
\hline
\end{tabular}

Table 3: Effect of fabric weight and color shade change at different concentrations of bleaching powder combined with $30 \%$ pumice stone.

\begin{tabular}{c|c|c|c|c}
\hline \multirow{2}{*}{$\begin{array}{c}\text { Bleaching } \\
\text { powder, } \\
\text { (g/L) }\end{array}$} & \multicolumn{2}{|c|}{ Fabric weight loss, (\%) } & \multicolumn{2}{c}{ Color shade loss, (\%) } \\
\cline { 2 - 5 } & $\begin{array}{c}\text { Bleaching with } \\
\text { soda ash }\end{array}$ & $\begin{array}{c}\text { Bleaching without } \\
\text { soda ash }\end{array}$ & $\begin{array}{c}\text { Bleaching with } \\
\text { soda ash }\end{array}$ & $\begin{array}{c}\text { Bleaching without } \\
\text { soda ash }\end{array}$ \\
\hline 0.0 & 0 & 0 & 0 & 0 \\
5.0 & 2.62 & 3.41 & 10 & 40 \\
7.5 & 3.94 & 4.46 & 20 & 50 \\
10.0 & 4.99 & 6.04 & 40 & 60 \\
12.5 & 5.51 & 6.82 & 50 & 70 \\
15.0 & 5.51 & 7.61 & 70 & 80 \\
\hline
\end{tabular}

Table 4: Effect of stiffness in warp and weft directions at different concentrations of bleaching powder combined with $30 \%$ pumice stone for denim garment.

\begin{tabular}{c|c|c|c|c}
\hline \multirow{2}{*}{$\begin{array}{c}\text { Bleaching } \\
\text { powder, } \\
(\mathbf{g} / \mathbf{L})\end{array}$} & \multicolumn{2}{|c|}{$\begin{array}{c}\text { Loss in stiffness in warp direction, }(\%) \\
\text { Loss in stiffness in weft direction, (\%) }\end{array}$} \\
\cline { 2 - 5 } & $\begin{array}{c}\text { Bleaching with } \\
\text { soda ash }\end{array}$ & $\begin{array}{c}\text { Bleaching without } \\
\text { soda ash }\end{array}$ & $\begin{array}{c}\text { Bleaching with } \\
\text { soda ash }\end{array}$ & $\begin{array}{c}\text { Bleaching without } \\
\text { soda ash }\end{array}$ \\
\hline 0.0 & 0 & 0 & 0 & 0 \\
5.0 & 26.67 & 20.00 & 6.2 & 3.1 \\
7.5 & 31.11 & 22.22 & 6.2 & 6.2 \\
10.0 & 31.11 & 24.44 & 9.4 & 6.2 \\
12.5 & 33.33 & 26.67 & 12.5 & 6.2 \\
15.0 & 33.33 & 26.67 & 12.5 & 9.4 \\
\hline
\end{tabular}

It can be seen from Table 2 that, treatment of denim trousers with $5.0 \mathrm{~g} / \mathrm{L}$ bleaching powder combined with $30 \%$ pumice stone caused more elongation, but with higher bleach concentrations from $7.5-15.0 \mathrm{~g} / \mathrm{L}$, elongation decreased in the both cases for soda ash and without soda ash. It is observed that due to more rubbing, fibers are decomposed more with higher bleach concentrations, as a result, elongation decreased than low bleach concentration. The stone-bleach washing with soda ash caused $23.14 \%$ elongation at $5.0 \mathrm{~g} / \mathrm{L}$ concentration of bleaching powder and at $15.0 \mathrm{~g} / \mathrm{L}$ bleach concentration elongation decreased to $14.33 \%$, and $12.95 \%$ and $6.89 \%$ elongation respectively for the case of without soda ash in warp direction. In weft direction, the stone- bleach washing with soda ash caused $4.88 \%$ elongation at $5.0 \mathrm{~g} / \mathrm{L}$ bleach concentration and $2.01 \%$ elongation at $15.0 \mathrm{~g} / \mathrm{L}$ bleach concentration, and $3.45 \%$ and $1.15 \%$ elongation, respectively for the case of without soda ash in bleach washing with $30 \%$ pumice stone.

Table 3 shows the weight loss of denim garments with the effect of bleaching powder concentration combined with $30 \%$ pumice stone. The Table showed that $7.61 \%$ weight loss was obtained with $15.0 \mathrm{~g} / \mathrm{L}$ bleaching powder concentration using without soda ash and the weight loss was $5.51 \%$ with soda ash. It can be seen from the Table that the color shade decreased after 
they were treated with soda ash and without soda ash at higher bleach concentrations particularly from 10.0$15.0 \mathrm{~g} / \mathrm{L}$ with $30 \%$ pumice stone. From the Table, it can be observed that the decrease in color shade at 5.0$15.0 \mathrm{~g} / \mathrm{L}$ bleaching powder with $30 \%$ pumice stone was higher for without soda ash $(80 \%$ loss $)$ than with soda ash $(70 \%$ loss $)$. The results disclose that increasing the bleach concentration from 5.0 to $15.0 \mathrm{~g} / \mathrm{L}$ with $30 \%$ pumice stone has effect on color shade change and weight loss of denim.

Table 4 shows denim decomposition by measuring the stiffness with the effect of bleach concentration combined with pumice stone. It can be seen that, the stiffness of the denim garment decreased at $5.0 \mathrm{~g} / \mathrm{L}$ bleach concentration with $30 \%$ pumice stone, and the decrease was more pronounced at higher bleach concentration. From the Table it is observed that at low concentration of $5.0 \mathrm{~g} / \mathrm{L}$ bleaching powder with soda ash caused $26.67 \%$ stiffness loss and without soda ash $20.0 \%$ loss and with higher concentration of $15.0 \mathrm{~g} / \mathrm{L}$

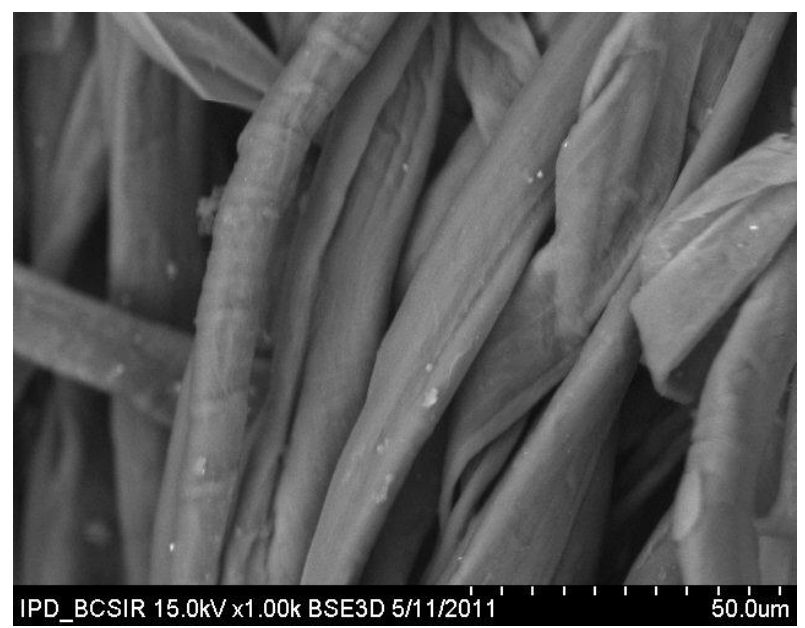

Fig. 1: SEM image of untreated denim fabric

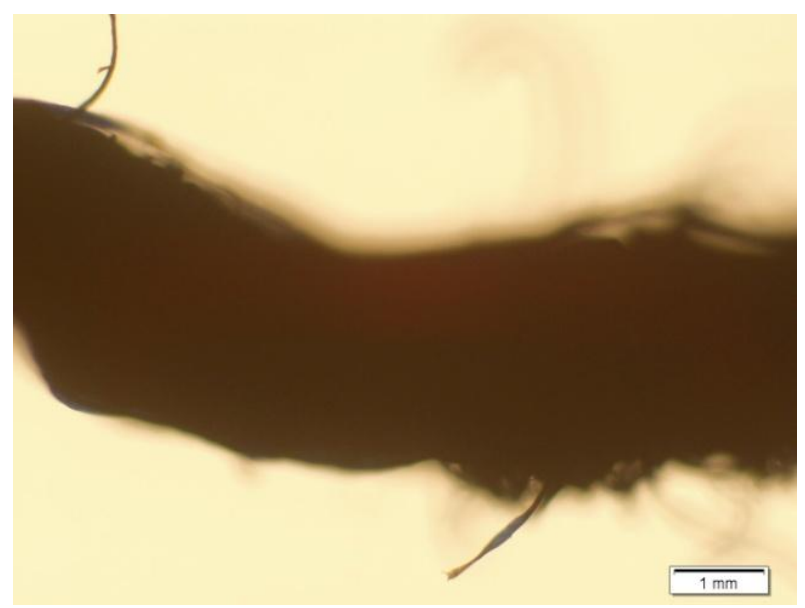

Fig. 3: FM image of untreated warp yarn of denim bleaching powder with pumice stone, the stiffness loss is higher in with soda ash than without soda ash and the values are $33.33 \%$ and $26.67 \%$ respectively. By stone-bleach treatment with increasing the concentration of bleaching powder, the fibers are loosened and softness increased.

\subsection{SEM Analysis}

Scanning electron microscopy was done on the untreated sample and after stone-bleach washed sample. Fig. 1 shows SEM images of untreated denim garment. The figure shows smoothened surfaces and no ruptures were visible in the images, because yarns are coated with sizing materials. Fig. 2 shows SEM images of stone-bleach treated denim garment. The figure shows more damaged and ruptured surfaces that are produced with the aqueous solution of bleaching powder and abrasions were due to rubbing by pumice stone in washing machine. As observed from the Fig. 2 , there are more damages on the surface of fibers.

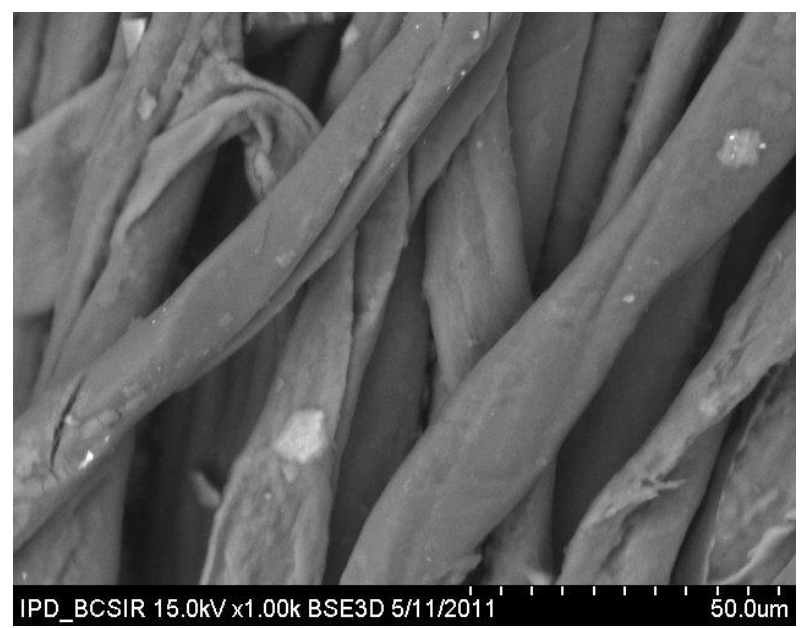

Fig. 2: SEM image of stone-bleach treated denim fabric

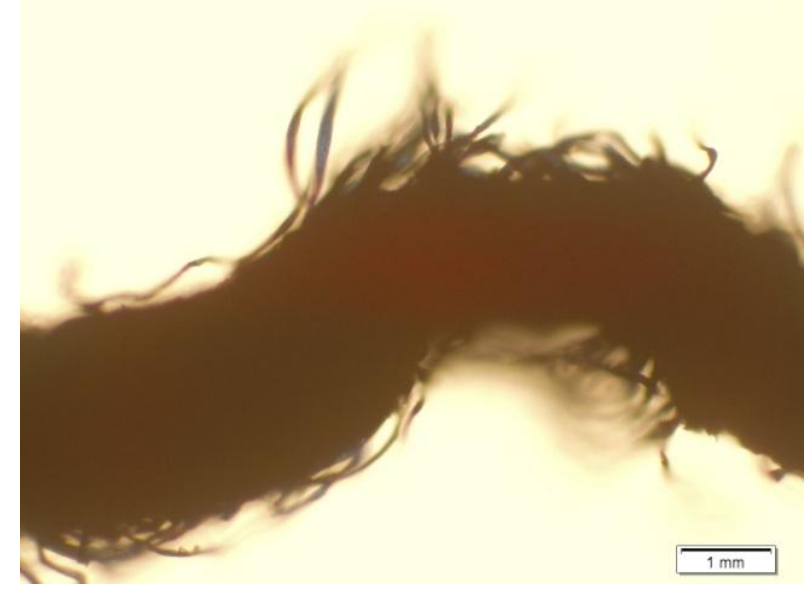

Fig. 4: FM image of stone-bleach treated warp yarn 


\subsection{FM Analysis}

The surface appearance of the fibers after the stonebleach treatments was studied by fluorescence microscopy. The Figs. 3-4 shows the change in physical appearances in the yarn surface of denim garment before and after washing with pumice stone combined with bleaching powder by fluorescence microscope (FM) (model IX71, Olympus, Japan). The Fig. 3 shows the fluorescence microscopy image of untreated warp yarn. The Figure shows smooth surface because the yarns are coated with size materials and projecting fibers are not visible on surface. The Fig. 4 shows the fluorescence microscopy photograph of warp yarn in stone-bleach washing with the concentration of $30 \%$ pumice stone combined with bleaching powder at $40^{\circ} \mathrm{C}$ for $20 \mathrm{~min}$. It is observed that the warp yarn surface is damaged by the rubbing action of pumice stone and the extent of damage is increased with the increasing of bleaching powder concentration of $15.0 \mathrm{~g} / \mathrm{L}$ in washing process.

\section{CONCLUSIONS}

In stone-bleach washing, the mechanical abrasions of pumice stone remove the dyes rapidly from the denim

\section{REFERENCES}

[1] Grieve, M., Biermann, T. and Schaub, K. (2006), The use of indigo derivatives to dye denim material, Science \& Justice, 46:15-24.

[2] Islam, M. T. (2010), Garments Washing \& Dyeing, Ananto Publications, Dhaka, , Pp. 220-222.

[3] Khan, M. M. R., Mondal, M. I. H. and Uddin, M. Z. (2012), Sustainable washing for denim garments by enzymatic treatment, Journal of Chemical Engineering, The Institution of Engineers (IEB), ChE 27(1): 27- 31 .

[4] Buchert, J. and Heikinheimo, L. (1998), New cellulase processes for the textile industry, Carbohydr. Eur. 22: 2-4.

[5] Duran, N. and Marcela, D., (2000), Enzyme applications in the textile industry, Review Progress in Coloration, 30 (1): 41-44.

[6] Wood, T. M., Fungal cellulases. Biochem. Soc. Transact., 20: 46-52 (1992). garment surface. The bleach combines with pumice stone help to get very lighter shade. Results show that the pumice stone in bleach washing accelerates more colour fading which affects on the fabric properties and has a more positive effect on producing new look faded fashion denim garment. It is concluded that the addition of pumice stone in denim washing with bleaching powder increases strength loss and this strength loss is lower compared with the result of stone-bleach washing without soda ash in treatments and $10.0 \mathrm{~g} / \mathrm{L}$ bleaching powder concentration mixed with pumice stone in stone-bleach washing with soda ash is the best value compared to all the fabric properties. Examination of the stone-bleach washed denim garments by SEM and FM shows more cracked and degraded on the surface, as a result fibers are damaged and weakened compared with unwashed denim.

\section{ACKNOWLEDGEMENTS}

One of the authors research work was supported by the NSICT Fellowship under the Ministry of Science and Information \& Communication Technology of the People's Republic of Bangladesh.

[7] Morries, C. E. and Harper, R. J. (1994), Comprehensive view on garment dyeing and finishing, American Dyestuff Reporter, 83: 132-136.

[8] Kang, I., Yang, C., Wei, W., \& Lickfield, G. C. (1998), Mechanical Strength of Durable Press Finished Cotton Fabrics, Part 1: Effects of Acid Degradation and Cross Linking of Cellulose by Polycarboxylic Acids, Textile Res. J., 68: 856-870.

[9] Heikinheimo, L., Buchert, J. and Suominen, P. (2000), Treating denim fabrics with trichoderma reesei cellulases, Textile Res. J. 70 (11) : 969-973.

[10] Sangita, S., Kumar, P. S. and Chandran, M. R. (2010), Types of stone wash \& their effects on the denim abric, The Indian Textile Journal.

[11] Khan, M. M. R., Mondal, M. I. H., Alam, A. B. M. F. and Hossain, M. H. (2012), Modification of denim garment with the treatment of bleaching powder, Can. J. on Chemical Engineering \& Technology, 3(2): pp. 30-36.

[12] Hams Group, personal communication. (2009), Hams Washing \& Dyeing Limited, 190 Tejgaon I/A, Dhaka,Bangladesh. 